\title{
PENGARUH KOMBINASI TEPUNG KUNYIT (Curcuma domestica VAL.) DAN PROBIOTIK TERHADAP PENAMPILAN USUS AYAM PEDAGING
}

\section{Effect of turmeric Powder Addition (curcuma domestica val.) and probiotic on the intestinal morphometric of broilers}

\section{Osfar Sjofjan ${ }^{1}$, Danung Nur Adli², Muhammad Halim Natsir ${ }^{1}$, Ajeng Kusumaningtyaswati ${ }^{3}$}

${ }^{1}$ Dosen, Fakultas Peternakan, Universitas Brawijaya, Malang, Jawa Timur 65145

${ }^{2}$ Mahasiswa Program Doktor, Fakultas Peternakan, Universitas Brawijaya, Malang, Jawa Timur 65145

${ }^{3}$ Mahasiswa Program Sarjana Fakultas Peternakan, Universitas Brawijaya, Malang, Jawa Timur 65145

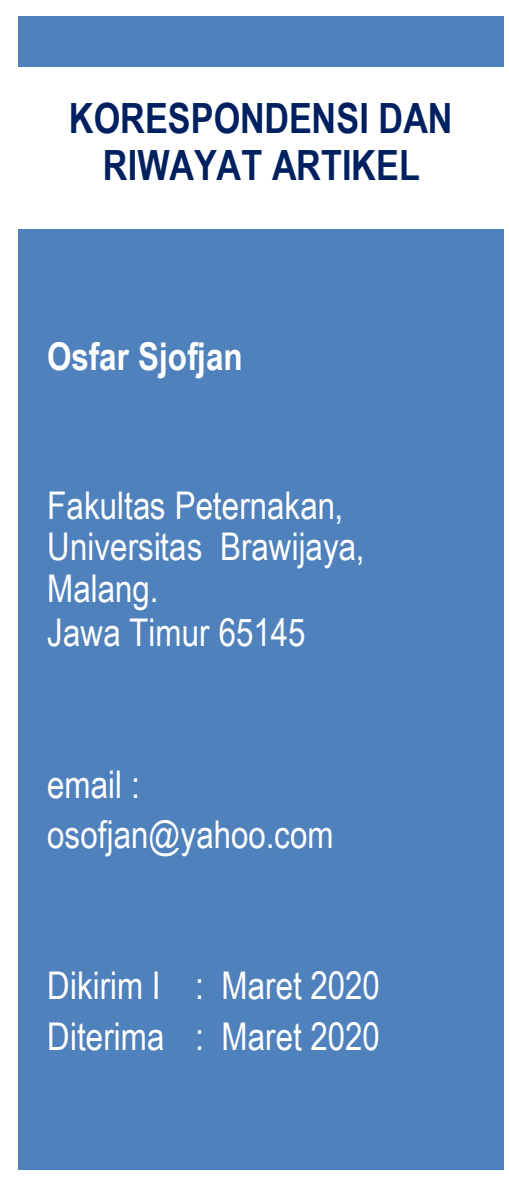

\begin{abstract}
ABSTRAK
Tujuan penelitian ini untuk mengetahui efek dari tepung kunyit dan probiotik terhadap karakteristik usus halus yang terdiri dari total vili, tinggi vili dan viskositas digesta. Materinya adalah 100 DOC (Day Old Chick) dan ukuran per plot $70 \times 80 \times 70 \mathrm{~cm}$ dibagi menjadi 20 plot. Data dianalisis secara statistik dengan menggunakan Analisis Variasi (anova). Jika data hasil yang berbeda signifikan antara perlakuan maka dilanjutkan dengan Uji Jarak Berganda Duncan. Dalam desain acak lengkap dengan empat perlakuan dan lima ulangan masing-masing dan 5 DOC per ulangan. Hasil dari penelitian ini adalah bahwa $0,1 \%$ penambahan tepung kunyit bubuk pada pakan secara signifikan meningkatkan jumlah vili usus halus. Penambahan tepung kunyit dan probiotik tidak memberikan perbedaan yang signifikan $(\mathrm{P}>0,05)$ terhadap tinggi viskositas vili dan vili usus halus. Disimpulkan bahwa serbuk kunyit dan probiotik dalam pakan ayam pedaging dapat meningkatkan jumlah vili. $0,1 \%$ tingkat perlakuan penambahan serbuk kunyit pada pakan broiler memberikan hasil terbaik menghasilkan jumlah total vili.
\end{abstract}

Kata kunci: kunyit, probiotik, vili, usus halus, ayam pedaging 


\begin{abstract}
The aim of this study was to find the effects of turmeric powder and probiotic addition to characteristics of small intestinal that consists of total of villous, height of villous and digesta viscosity. The material were 100 DOC and size per plot $70 \times 80 \times 70 \mathrm{~cm}$ are divided into 20 plots. The data were analyzed with statistically by using analysis of variance (ANOVA). If the data significant different results between the treatment then continued with the Multiple Range Test Duncan's. In a completely randomized design with four treatments and five replicates each and 5 DOC per replicate. The results of this study were that $0,1 \%$ of turmeric powder addition on feed significantly increases the total of villous of small intestine. Turmeric and probiotic powder addition doesn't gave the significant difference $(\mathrm{P}>0,05)$ to height of villous and digesta viscosity of the small intestine. The concluded was turmeric powder addition and probiotic in broiler feed can increased the total of villous. $0,1 \%$ treatment level turmeric powder addition on feed broiler gave the best results had produced total number of villous.
\end{abstract}

Keywords: Turmeric, probiotic, villous, small intestine, broiler.

\section{PENDAHULUAN}

Pertambahan jumlah penduduk di Indonesia dari tahun ke tahun terus mengalami peningkatan, hal ini akan berdampak pada peningkatan konsumsi produk peternakan (daging) yang secara tidak langsung memberikan peluang usaha dalam memajukan industri peternakan Indonesia termasuk perunggasan. (Adli, dkk, 2017). Ternak unggas memberikan kontribusi yang besar terhadap pemenuhan gizi khususnya protein hewani. Kunyit merupakan tanaman herbal yang memiliki sifat antibakteri kunyit dapat mengurangi jumlah bakteri patogen, meningkatkan pertumbuhan bakteri yang menguntungkan dalam saluran pencernaan sehingga dapat meningkatkan kesehatan saluran cerna ayam (Alfian, dkk.,2015).

Minyak atsiri yang terkandung di dalam kunyit dapat mempercepat pengosongan isi lambung. Kunyit dapat digunakan sebagai antibiotik alami karena mempunyai kemampuan dalam menekan mikroba patogen (Adli et al., 2019). Probiotik merupakan makanan tambahan berupa mikroba hidup baik bakteri maupun kapang yang mempunyai pengaruh menguntungkan pada hewan inang dengan memperbaiki mikroba dalam saluran pencernaan. Probiotik sebagai mikroorganisme hidup jika diberikan dalam jumlah yang cukup memberikan manfaat pada sistem pencernaan yaitu dapat mengurangi populasi patogen yang terdapat dalam usus (Hamida, dkk., 2015).

Probiotik dapat meningkatkan bakteri asam laktat dalam usus ayam, sedangkan kunyit dapat membuat kondisi mikroba non patogen seimbang dan menurunkan kadar bakteri patogen. Perbaikan nilai nutrisi dalam pakan dapat dilakukan dengan menambahkan proporsi tepung kunyit dan probiotik. Kombinasi dari kedua campuran pakan saling bersinergi dalam mengontrol bakteri patogen dalam usus halus ayam pedaging, sehingga usus halus maksimal dalam proses penyerapan nutrisi, maka pertambahan bobot badan akan meningkat. Menurut Alfian, dkk. (2015), probiotik dan kunyit memiliki fungsi yang dapat saling melengkapi.

Probiotik dapat meningkatkan kinerja organ pencernaan ayam sedangkan kunyit mampu meningkatkan relaksasi usus halus yang mengurangi gerakan peristaltik usus halus dan ingesta akan lebih lama tinggal di usus halus sehingga absorpsi zat-zat makanan akan lebih sempurna.

Berdasarkan uraian diatas penelitian yang dilakukan adalah untuk mengetahui penambahan tepung kunyit dan probiotik terhadap karakteristik usus ayam pedaging yang meliputi jumlah vili, tinggi vili dan viskositas digesta. Untuk itu perlu dikaji mengenai penambahan tepung kunyit (Curcuma domestica Val.) dan probiotik dalam pakan. 


\section{METODE PENELITIAN}

Materi yang digunakan yaitu DOC (Day Old Chick) strain Cobb sebanyak 100 ekor yang tidak dibedakan jenis kelaminnya (unsexed) dipelihara selama 35 hari di kandang peternakan ayam pedaging Jl. Melati Desa Dadaprejo, Kecamatan Junrejo, Kota Batu. Kandang dari penelitian memiliki ukuran $70 \times 80 \times 70 \mathrm{~cm}$ setiap plot yang berjumlah 20 plot. Aditif pakan yang digunakan adalah kunyit yang diperoleh dari UPT. Materia Medica dan probiotik memiliki TPC $4,72 \times 10^{8} \mathrm{CFU} / \mathrm{ml}$ dalam bentuk tepung. Peralatan yang digunakan yaitu plastik terpal, sekam, kertas koran, timbangan digital,
(Widiyawati dkk, 2020). Teknologi fermentasi adalah proses penanaman inokulan yang sesuai ke dalam suatu substrat yang dilanjutkan inkubasi pada suhu dan waktu tertentu dengan tujuan terjadinya proses fermentasi yang dapat meningkatkan nilai nutrisi terutama kadar protein (Adli dan Sjofjan, 2018). Data hasil penelitian dianalisis dengan menggunakan SAS Version 4.0 dengan Rancangan Acak Lengkap (RAL) dan analisis statistik menggunakan analisis ragam (anova)Apabila hasil penelitian menunjukkan pengaruh nyatta $(\mathrm{P}<0,05)$ atau sangat nyata $(\mathrm{P}<0,01)$ maka dilanjutkan dnegan Uji Jarak Berganda Duncan's (UJBD). Metode dalam RAL yang digunakan

Tabel 1. Kandungan Zat Makanan Bahan Pakan Penelitian

\begin{tabular}{lcccccc}
\hline $\begin{array}{l}\text { Bahan } \\
\text { pakan }\end{array}$ & $\begin{array}{c}\text { Eenrgi } \\
\text { Metabolis } \\
(\text { Kkal/g) }\end{array}$ & $\begin{array}{c}\text { Protei } \\
\text { Kasar } \\
(\%)\end{array}$ & $\begin{array}{c}\text { Serat } \\
\text { Kasar } \\
(\%)\end{array}$ & $\begin{array}{c}\text { Lemak } \\
\text { Kasar } \\
(\%)\end{array}$ & $\begin{array}{c}\text { Kalsium } \\
(\%)\end{array}$ & $\begin{array}{c}\text { Pospor } \\
(\%)\end{array}$ \\
\hline Jagung $^{\mathrm{a}}$ & 3226 & 9,20 & 2,74 & 5,46 & 0,01 & 0,26 \\
Konsentrat $^{\mathrm{b}}$ & 2700 & 41,00 & 5,00 & 5,00 & 2,50 & 1,40 \\
Bekatul $^{\mathrm{a}}$ & 2860 & 12,00 & 12,00 & 3,00 & 0,04 & 1,40 \\
\hline
\end{tabular}

Keterangan :

${ }^{a}$ Hasil Analisis Laboratorium Pakan Ternak Dinas Peternakan dan Perikanan Blitar

${ }^{b}$ Label pakan konsentrat PT. Japfa Comfeed.

ember, termometer, vaksin, obat-obatan, dan kalkulator.

Metode penelitian yang digunakan dalam penelitian ini adalah metode percobaan dengan menggunakan Rancangan Acak Lengkap (RAL) dengan 4 perlakuan dan 5 ulangan:

P0 =Pakan basal tanpa penambahan tepung kunyit dan probiotik; $\mathrm{P} 1=$ Pakan basal $+0,1 \%$ penambahan tepung kunyit (fitobiotik); P2 =Pakan basal $+0,1 \%$ penambahan tepung probiotik; $\mathrm{P} 3=$ Pakan basal $+0,05 \%$ penambahan tepung kunyit (fitobiotik) dan $0,05 \%$ probiotik.

Variabel yang diamati pada penelitian ini meliputi: tinggi vili, jumlah vili dan viskositas digesta.. Metode yang digunakan adalah pewarnaan hematoxilin dan eosin adalah sebagai berikut :

$$
Y i j=\mu+\pi i+\varepsilon i j
$$

Keterangan: Yij = Nilai pengamatan pada perlakuan ke-i ulangan ke $\mathrm{j} ; \mu=$ Nilai tengah umum; $\pi \mathrm{i} \quad=$ Pengaruh perlakuan ke-I; $E \mathrm{ij}=$ Kesalahan (galat) percobaan pada perlakuan i (Perlakuan ke 0, 1, 2, 3, 4) dan ulanagn $\mathrm{j}$ ke- $1,2,3,4$

\section{HASIL DAN PEMBAHASAN}

Berdasarkan hasil penelitian mengenai efek penambahan tepung kunyit (Curcuma domestica Val.) dan probiotik terhadap jumlah vili, tinggi vili dan viskositas digesta usus ayam pedaging melalui pencampuran pakan basal sebagai feed additive dapat dilihat pada Tabel 2 . 
Tabel 1. Rataan Jumlah Vili, Tinggi Vili dan Viskositas Digesta Ayam Pedaging

\begin{tabular}{cccc}
\hline \multirow{2}{*}{ Perlakuan } & \multicolumn{3}{c}{ Variabel Pengamatan } \\
\cline { 2 - 4 } & Jumlah Vili & $\begin{array}{c}\text { Tinggi Vili } \\
(\mu \mathrm{m})\end{array}$ & $\begin{array}{c}\text { Viskositas Digesta } \\
(\text { CPs })\end{array}$ \\
\hline P0 & $62,80^{\mathrm{a}}$ & $699,25^{\mathrm{a}}$ & $3,27^{\mathrm{a}}$ \\
P1 & $87,90^{\mathrm{d}}$ & $696,22^{\mathrm{a}}$ & $3,96^{\mathrm{a}}$ \\
P2 & $80,90^{\mathrm{c}}$ & $631,21^{\mathrm{a}}$ & $4,18^{\mathrm{a}}$ \\
P3 & $72,20^{\mathrm{b}}$ & $646,29^{\mathrm{a}}$ & $4,10 \mathrm{a}$ \\
\hline
\end{tabular}

Keterangan : Superskrip huruf yang berbeda dalam kolom yang sama menunjukkan pengaruh nyata $(\mathrm{P}<0,05)$.

Tabel 2 menunjukkan bahwa pengaruh pemberian tepung kunyit (Curcuma domestica Val.) dan probiotik pada pakan ayam pedaging memberikan pengaruh yang nyata $(\mathrm{P}<0,05)$ terhadap jumlah vili usus halus ayam pedaging. Nilai yang paling rendah yaitu pada perlakuan P0. Nilai perlakuan P1 dengan penambahan kunyit dan perlakuan P2 dengan penambahan probiotik memiliki nilai yang tidak berbeda jauh.

Adanya pengaruh yang nyata ini disebabkan karena penambahan kunyit yang mengandung minyak atsiri dapat menurunkan jumlah bakteri patogen yang dapat merusak vili dan meningkatkan bakteri asam laktat yang dapat menambah tingkat kerapatan vili sehingga jumlah vili semakin banyak. Perlakuan P2 dan P3 kurang efektif dikarenakan level penambahan probiotik dan kunyit yang sedikit sehingga patogen mampu merusak vili dalam usus halus ayam pedaging dan tingkat ketahanan bakteri yang rendah.

Perlakuan P1 lebih tinggi dari perlakuan P3 karena kunyit memiliki antibiotik yang dapat meminimalisir aktivitas bakteri patogen. Menurut pendapat Adli, dkk. (2018) bahwa sifat antibakteri kunyit dapat mengurangi jumlah bakteri patogen, meningkatkan pertumbuhan bakteri yang menguntungkan dalam saluran pencernaan sehingga dapat meningkatkan kesehatan saluran cerna ayam. Hasil analisis statistik data penelitian tinggi vili usus halus ayam pedaging diperoleh bahwa efek penambahan tepung kunyit (Curcuma domestica Val.) pada pakan ayam pedaging tidak memberikan pengaruh yang nyata $(\mathrm{P}>0,05)$ terhadap tinggi vili usus halus ayam pedaging. Hal ini sependapat dengan penelitian yang telah dilakukan oleh Rahmah, dkk. (2013) bahwa penambahan campuran herbal hingga level $1,5 \%$ belum memberikan pengaruh yang cukup pada proses penyerapan nutrisi.

Selain itu juga dapat dipengaruhi oleh pertumbuhan BAL yang belum maksimal di dalam usus halus. BAL dan Escheria coli masih berkompetisi dalam mendapatkan nutrisi pakan, sehingga BAL belum dapat bekerja secara maksimal dalam vili usus dan belum mampu membantu meningkatkan penyerapan nutrien pakan dengan memperpanjang dan memperluas vili usus. Hasil penelitian dari Asmarasari, dkk. (2008) menunjukkan bahwa pemberian kunyit dalam pakan juga tidak memberikan pengaruh. Percobaan penelitian minyak atsiri dalam tepung kunyit kemungkinan besar telah mengalami penguapan saat proses pembuatan tepung kunyit. Minyak atsiri sendiri bersifat mudah menguap karena titik uapnya yang rendah. Hasil dari beberapa penelitian tidak selalu mendapatkan hasil yang nyata maupun sangat nyata, meskipun pada ternak itik menunjukkan adanya pengaruh atsiri terhadap morfometrik ileum (Mushawwir dkk., 2019).

Berdasarkan hasil analisis statistik, menunjukkan hasil viskositas digesta usus 
halus ayam pedaging tidak ada perbedaan yang nyata $(\mathrm{P}>0,05)$ terhadap masing-masing perlakuan yang digunakan. Hal ini diduga pada level pemberian tepung kunyit maupun probiotik kurang tinggi sehingga tidak memberikan efek pada viskositas digesta untuk mencerna nutrisi lebih efektif. Berbeda dengan hasil penelitian Natsir, dkk., (2016) yang menyatakan bahwa pemberian kunyit dan jahe berpengaruh sangat nyata pada viskositas digesta, namun memiliki efek negatif jika viskositas usus halus meningkat, maka akan mengurangi efisiensi pencernaan dengan memperlambat laju difusi enzim endogenous untuk bereaksi dengan nutrien, serta mempebaiki biokimia darah pada puyuh dan broiler (Mushawwir et al., 2017,2018).

Sementara menurut Sjofjan, dkk. (2015) menyampaikan bahwa viskositas digesta yang meningkat mengakibatkan proses laju digesta menjadi lambat dan memungkinkan terjadi peningkatan proses pencernaan dan penyerapan zat makanan lebih efektif, sehingga ketersediaan nutrien untuk sintesis jaringan tubuh meningkat.

\section{KESIMPULAN}

Penambahan tepung kunyit dan probiotik dalam pakan ayam pedaging dapat meningkatkan jumlah vili usus halus dan tidak dapat meningkatkan nilai tinggi vili

\section{DAFTAR PUSTAKA}

Adli, D. N., O. Sjofjan and M. Mashudi. 2017. Dried of poultry waste ureamolasses block (dpw-umb) as potential for feed Supplementation. Jurnal Agripet, 17:144-149.

Adli, D. N. and O. Sjofjan. 2018. Nutrient content evaluation of dried poultry waste urea molasses block (DPWUMB) on In-vitro analysis. Sains Peternakan, 16:50-53.

Adli, D. N., O. Sjofjan and M. Mashudi. 2018. Nutrient content evaluation of dried poultry waste urea-molasses block (dpw-umb) on proximate analysis. J. Ilmu-Ilmu Peternakan. 28:84-89.

Adli, D. N., Y. Chi, J.W. Lee dan O. Sjofjan. 2019. Supplementation mannan-rich fraction (MRF) and/or combination with probiotic-enhanced water acidifier on dietary female broiler at 28 days as natural growth promoters (NGPs). Research J. of Advanced Engineering and Sci. 4:427-429.

Alfian, N.A. dan Munir. 2015. Pengaruh pemberian tepung lempuyang (Zingiber aromaticum Val.) dan tepung kunyit (Curcuma domesticus) terhadap konsumsi dan konversi ransum broiler. Sidenreng Rappang. J. Galung Tropika. 4:50-59.

Asmarasari, S. A. dan E. Suprijatna. 2008. Pengaruh penggunaan kunyit dalam ransum terhadap performans ayam pedaging. Bogor. 17:657-661.

Hamida, F., K.G. Wiryawan and A. Meryandini. 2015. Selection of lactic acid bacteria as probiotic candidate for chicken. Bogor. Media Peternakan. 38:138-144.

Mushawwir, A, U. H. Tanuwiria, K.A. Kamil, L. Adriani and R. Wiradimadja. 2017. Effects of volatile oil of garlic on feed utilization, blood biochemistry and performance of heat-stressed japanese quail. Asian J. of Poult. Sci. 11:83-89.

Mushawwir, A, U.H. Tanuwiria, Kurnia Kamil, L. Adriani, R. Wiradimadja, and N. Suwarno. 2018. Evaluation of haematological responses and blood biochemical parameters of heat-stressed broilers with dietary supplementation of Javanese Ginger powder (Curcuma xanthorrhiza) and garlic extract (Allium sativum). International J. of Poult. Sci .17:452-458.

Mushawwir, A., N. Suwarno, A.A. Yulianti dan R. Permana. 2019. Dampak pemberian minyak atsiri bawang putih terhadap histologi illeum itik cihateup fase pertumbuhan yang 
dipelihara sacara ekstensif. Jurnal Peternakan Sriwijaya. 8:35-44.

Natsir, M.H., E. Widodo dan Muharlien. 2016. Penggunaan kombinasi tepung kunyit (Curcuma domestica) dan jahe (Zingiber officinale) bentuk enkapsulasi dan tanpa enkapsulasi terhadap karakteristik usus dan mikroflora usus ayam pedaging. Malang. Buletin Peternakan. 40:1-10.

Rahmah, A., N. Suthama dan V.D. Yunianto. 2013. Total bakteri asam laktat dan Escherichia coli pada ayam broiler yang diberi campuran herbal dalam ransum. Semarang. Anim. Agriculture J. 2:39-47.

Sjofjan, O., M.H. Natsir dan T. Ardianti. 2015. Efek penggunaan probiotik kultur campuran dalam air minum terhadap karakteristik dan mikroflora usus ayam petelur. 1:52-58.

Sjofjan, O., D. N. Adli, P.K. Hanani and D. Sulistiyaningru. 2019. The utilization of bay leaf (SyzygiumpolyanthumWalp) Flour in feed on carcass quality, microflora instestine of broiler. International $\mathrm{J}$. of Engineering Technologies and Management Research. $6: 1-9$

Widiyawati, I., O. Sjofjan dan D.N. Adli. 2020. Peningkatan kualitas dan persentase karkas ayam pedaging dengan subtitusi bungkil kedelai menggunakan tepung biji asam (Tamarindus indica L) fermentasi. J. Nutrisi Ternak Tropis. 3:35-40. 